\title{
Muscle Spasm
}

National Cancer Institute

\section{Source}

National Cancer Institute. Muscle Spasm. NCI Thesaurus. Code C50656.

A sudden, violent, involuntary contraction of a muscle or group of muscles. 